\title{
PENGARUH PEMUTUSAN HUBUNGAN KERJA ( PHK ) DAN POTONG GAJI TERHADAP KESEHATAN MENTAL KARYAWAN UMKM DI LAMPUNG TIMUR PADA ERA PANDEMIC COVID 19
}

\author{
${ }^{1}$ Susi Sulastri \\ ${ }^{2}$ Dede \\ Prodi Manajemen, Sekolah Tinggi Ilmu Ekonomi Lantim Way Jepara \\ susisulastri.stielt@gmail.com ${ }^{1}$ dedeharjadisastra@gmail.com $^{2}$
}

\begin{abstract}
ABSTRAK
Indonesia merupakan salah satu Negara yang terpapar covid 19, yang pada akhirnya para pekerja mengalami efek dari covid. Jumlah pekerja yang terdampak situasi pandemi Covid-19 mencapai 1,7 juta orang baik pekerja formal maupun informal, dan diperkirakan akan terjadi penambahan pengangguran yang diestimasi mencapai 2,92 hingga 5,23 juta orang ( Kemeknaker, 2020). Salah satu penyebab begitu banyaknya pengangguran selama pandemi covid ini, adalah karena perusahaan tidak lagi mampu membayar karyawannya, sehingga terpaksa melakukan pemutusan hubungan kerja dengan karyawannya. Penelitian ini bertujuan untuk mengatahui dan menganaslisis pengaruh Pemutusan hubungan kerja (PHK), Pemotongan gaji terhadap kesehatan mental karyawan Usaha mikro kecil dan menengah (UMKM) di Lampung. Metode penelitian yang penulis gunakan adalah metode kuatitatif. Teknik pengumpulan data menggunakan kuesioner yang diberikan kepada karyawan yang tersisa atau tidak terkena PHK di UMKM di Lampung Timur . Jumlah populasi yaitu 292. Teknik analisis data menggunakan rumus regresi linear, dengan bantun SPSS. Hasil penelitian menunjukan bahwa terdapat pengaruh negatif pemutusan hubungan kerja (PHK) terhadap kesehatan mental karyawan UMKM di Lampung Timur, selain itu juga diketahui bahwa terdapat pengaruh negatif Pemotongan gaji terhadap kesehatan mental karyawan UMKM di Lampung Timur. Hasil penelitian ini diharapkan dapat menjadi masukan bagi pembuat kebijakan (manajer dan pemilik UMKM) dalam upaya menjaga kesehatan mental karyawan.
\end{abstract}

Kata kunci: Pemutusan hubungan kerja (PHK), Pemotongan gaji, kesehatan mental karyawan Usaha mikro kecil dan menengah (UMKM)

\begin{abstract}
Indonesia is one of the countries exposed to covid 19, which in the end the workers experienced the effects of covid. The number of workers affected by the Covid-19 pandemic situation has reached 1.7 million people, both formal and informal workers, and it is estimated that there will be an increase in unemployment which is estimated to reach 2.92 to 5.23 million people (Kemeneknaker, 2020). One of the causes of so many unemployment during this covid pandemic is because companies are no longer able to pay their employees, so they are forced to terminate employment with their employees. This study aims to identify and analyze the effect of termination of employment (PHK), salary deductions on the mental health of employees of Micro, Small, and Medium Enterprises (MSMEs) in Lampung. The research method that the author uses is a quantitative method. The data collection technique used a questionnaire given to employees who were left or not affected by layoffs at MSMEs in East Lampung. The total population is 292. The data analysis technique uses a linear regression formula, with the help of SPSS. The results showed that there was a negative effect of termination of employment (PHK) on the mental health of MSME employees in East Lampung, besides that it was
\end{abstract}


also known that there was a negative effect of salary deductions on the mental health of MSME employees in East Lampung. The results of this study are expected to be input for policymakers (managers and owners of MSMEs) to maintain the mental health of employees.

Keywords: Termination of employment (PHK), salary deductions, the mental health of employees Micro, small and medium enterprises (MSMEs).

\section{PENDAHULUAN}

Masa pandemic covid, berawal dari China, kemudia merebak ke seluruh penjuru Dunia. Pandemi yang tengah melanda seluruh bagian dunia, termasuk Indonesia, aspek ketenagakerjaan merupakan salah satu bidang yang terkena imbasnya secara signifikan. Banyak perusahaan yang menunda proses hiring, memberlakukan lay off atau cuti tanpa gaji, hingga memberhentikan karyawan-karyawannya dalam rangka efisiensi dan mempertahankan keberlangsungan usaha yang sedang menghadapi perekonomian yang lesu.

Indonesia merupakan salah satu Negara yang terpapar covid 19, yang pada akhirnya para pekerja mengalami efek dari covid. Jumlah pekerja yang terdampak situasi pandemi Covid-19 mencapai 1,7 juta orang baik pekerja formal maupun informal, dan diperkirakan akan terjadi penambahan pengangguran yang diestimasi mencapai 2,92 hingga 5,23 juta orang ( Kemeknaker, 2020). Salah satu penyebab begitu banyaknya pengangguran selama pandemi covid ini, adalah karena perusahaan tidak lagi mampu membayar karyawannya, sehingga terpaksa melakukan pemutusan hubungan kerja dengan karyawannya.

Dalam ketentuan pasal 1 ayat 15 mendefinisikan Hubungan Kerja adalah hubungan antara pengusaha dengan pekerja/buruh berdasarkan perjanjian kerja, yang mempunyai unsur pekerjaan, upah dan perintah. Kedua, pasal 1 ayat 14 yang menjelaskan bahwa perjanjian kerja adalah perjanjian antara pekerja/buruh dengan pengusaha atau pemberi kerja yang memuat syarat-syarat kerja, hak, dan kewajiban para pihak. Ketiga, menurut pasal 1 ayat 25 dijelaskan bahwa Pemutusan Hubungan Kerja (PHK) adalah pengakhiran hubungan kerja karena suatu hal tertentu yang mengakibatkan berakhirnya hak dan kewajiban antara pekerja/buruh dan pengusaha. Hak pekerja yang secara normatif diatur dalam UndangUndang Nomor 13 Tahun 2003 Pasal 156 tentang Ketenagakerjaan untuk pekerja yang mengalami PHK adalah hak pekerja/buruh untuk memperoleh uang pesangon, uang penghargaan masa kerja, dan uang penggantian hak yang seharusnya diterima.

Pemutusan hubungan kerja ( PHK) menjadi keharusan bagi perusahaan besar maupun kecil yang tidak mampu survive. Langkah PHK dilakukan demi penghematan biaya dan menyelamatkan bisnis perusahaan. Keputusan ini bukan merupakan keputusan yang mudah. Perusahaan pastinya telah mencoba segala kemungkinan untuk menghindari hal tersebut 
terjadi tetapi perusahaan juga harus menerima kenyataan bahwa keputusan hari ini kami ambil demi jutaan mata pencaharian orang yang bergantung pada perusahaan.

Banyak cara perusahaan memutuskan hubungan kerja dengan karyawan. Jika PHK yang dilakukan perusahaan ternyata dirasa tidak adil oleh karyawan. Di satu sisi, karyawan mungkin menganggap pemecatan atau pemotongan upah sebagai hal yang kurang adil di masa-masa pengangguran tinggi daripada selama periode pasar tenaga kerja yang kurang berbahaya: Semakin tinggi tingkat pengangguran regional, semakin kecil kemungkinannya untuk menemukan pekerjaan baru dengan kondisi pekerjaan yang serupa, (Struck. 2006).

PHK yang keras dianggap agak tidak adil di Jerman dan juga di Amerika Utara. PHK yang lembut,bagaimanapun, memberikan dampak yang jauh lebih kuat pada persepsi keadilan di Amerika Utara daripada di Jerman. Ini mungkin sebagian karena tunjangan yang lebih rendah dan perlindungan sosial yang kurang selama pengangguran di Amerika Utara, (Gerlach:2006).

Bagaimanapun cara perusahanan memutuskan hubungannya dengan perusahaan. Entah adil atau tidak adil, tetap saja menyisakan dampak, Tidak hanya memengaruhi karyawan yang kehilangan pekerjaan, tetapi juga mereka yang tetap di perusahaan perampingan bahkan jika mereka sendiri tidak diberhentikan (Black et al. 2015). Salah satu dampaknya adalah, kecemasan dan ketakutan. Ketakutan mereka mungkin dipengaruhi oleh ketidakpastian mengenai keamanan pekerjaan mereka, terkait dengan rasa takut menjadi orang berikutnya yang akan diberhentikan, dan mengalami perasaan pekerjaan ketidakamanan, yang mungkin memiliki efek buruk pada status kesehatan mereka (Caroli dan Godard, 2016).

Hasil penelitian Lille (2019) menunjukkan bahwa, untuk karyawan yang tersisa, dari PHK massal menghasilkan efek negatif yang signifikan pada kesehatan mental mereka. Artikel serupa, kehilangan pekerjaan berpengaruh pada hasil kesehatan; penelitian menunjukkan dampak negatif yang signifikan terhadap kesehatan bagi pekerja yang kehilangan pekerjaan karena PHK massal atau penutupan perusahaan ( Sullivan dan Von Waechter, 2009 ).

Pemutusan hubungan kerja ( PHK) dan pemotongan gaji bisa berefek negatif kesehatan mental dan dari waktu ke waktu menumpuk dan bermanifestasi menjadi kesehatan fisik yang lebih buruk. Misalnya, kesehatan fisik mungkin bukan hanya dipengaruhi oleh perubahan standar hidup, tetapi juga meningkatkan kerusakan kesehatan dan penurunan perilaku promosi kesehatan ( Nizalova \& Norton, 2017 ). Terakhir, penelitian sebelumnya menyoroti bahwa efek negatif dampak psikologis dari waktu ke waktu dapat diterjemahkan menjadi masalah kesehatan fisik (Korpi, 2001). 
Sullivan dan Von Watcher (2006) menyatakan bahwa tingkat kematian nampak meninggi secara mencolok pada tahun-tahun setelah PHK Massal. Sullivan dan Von Watcher ini pada tahun 2006 melakukan analisa terhadap data administratif dari pekerja di Pennsylvania pada tahun 1970 hingga 1980, dipasangkan dengan data dari Data kematian dalam lembaga Administrasi Jaringan Sosial sejak tahun 1980 hingga 2006. Penelitian tersebut dilakukan di Pennsylvania setelah peristiwa PHK massal di tahun 1970 - 1980 karena resesi ekonomi terjadi.

Darity dan Goldsmith pada tahun 1996 yang menyatakan bahwa kehilangan pekerjaan memiliki pengaruh langsung kepada keadaan mental seseorang. Bahwa dalam berbagai literatur psikologi, telah diteliti bahwa setelah kehilangan pekerjaan muncul gejala rendahnya kepuasan kerja, depresi, harga diri rendah, ketidakbahagiaan, dan bahkan bunuh diri. Hal-hal tersebut muncul karena menurunnya pendapatan, namun ada hal-hal lain lagi yang muncul karena pekerjaan bukan satu-satunya sumber pendapatan, namun juga menyediakan interaksi sosial, memberi identitas yang baik di masyarakat, dan mempengaruhi rasa percaya diri para korban PHK tersebut.

Hasil penelitian terdahulu telah menunjukan bahwa dampak PHK dan pemotongan gaji pada umumnya bersifat negatif terhadap kesehatan mental karyawan. Efek negatif tersebut terjadi di beberapa negara, Jerman dan Amerika Utara, (Gerlach:2006), dan banyak lagi negara lain. Indonesia sendiri pernah mengalami beberapa kali PHK masal. Masalah PHK dan Potong gaji pernah dirasakan masyarakat Indonesia sebagai buntut dari krisis ekonomi 2008, besarnya aktivitas perampingan telah diintensifkan, yang mengarah ke peningkatan proporsi karyawan yang terpapar massa . Berbeda dengan masa krisis atau resisi yang disebabkan dengan perang, PHK dilaksanakan oleh perusahaan akan terasa lebih berat lagi dirasakan oleh karyawan, karena terjadi pada musim pandemic. Karyawan tidak hanya mengalami masalah pada pekerjaan, tetapi mereka juga dibayang-bayangi oleh pandemic yang terjadi.

Pemutusan hubungan kerja ( PHK), Pemotongan gaji dan kesehatan mental telah banyak diteliti di berbagai negara. Sullivan dan Von Watcher, (2006), lokasi penelitian di Pennsylvania. Gerlach: ((2006), Jerman dan Amerika Utara, Voßemer, 2018 di Eropa. Kumar Mishra dan Bhatnagar (2010) meneliti hubungan organisasi identifikasi dan disonansi emosional dengan intensi turnover dan kesejahteraan di antara sampel dari 468 perwakilan medis di industri farmasi India. Metgud et al., (2008) pada sampel dari 100 pekerja wanita di bagian pemintalan dari wol padat karya skala kecil pabrik tekstil di Karnataka. Oswald \& Wu (2011) dieksplorasi geografi kesejahteraan manusia, di mana kesehatan mental dan kepuasan 
hidup di antara sampel acak 1,3 juta, data penduduk AS dikumpulkan antara 2005-2008. Selain dilakukan dibeberapa negara, ternyata PHK juga dilakukan dengan berbagai sebab,diantara adalah karena masa setelah perang, krisis global, perang dagang, bencana alam dan karena pandemic.

Perbedaan Lokasi penelitian dan perbedaan faktor eksternal tersebut menjadi dasar dalam penelitian ini untuk meneliti Gaji, Potong Gaji dan Kesehatan Mental Karyawan Dalam Penelitian ini, peneliti bertujuan mengatasi kesenjangan dalam memahami faktor penyebab PHK, Potong gaji dan Kesehatan Mental karyawan. Selain itu melihat adanya efek negatif PHK, potong gaji terhadap kesehatan mental karyawan, maka perusahaan perlu memperhatikan kesehatan mental karyawan .Kesehatan mental yang buruk bisa mengurangi efisiensi organisasi dan memiliki implikasi sosial yang lebih luas dengan cara mengurangi kesehatan fisik, yang mengarah pada meningkatnya biaya medis (Tsui, 2013). Karyawan yang bahagia dan sehat adalah tulang punggung organisasi yang hebat.

Berdasarkan latar belakang, kesenjangan penelitian, dan fenomena bisnis yang telah diuraikan di atas, terdapat masalah yang harus diselesaikan yaitu adanya perbedaan era PHK dan Potong gaji yang dirasakan karyawan, yaitu era pandemic. Penelitian ini bertujuan untuk mengatahui dan menganaslisis Dampak Pemutusan hubungan kerja ( PHK), Pemotongan gaji terhadap kesehatan mental karyawan Usaha mikro kecil dan menengah (UMKM) di Lampung. Hasil penelitian ini diharapkan dapat menjadi masukan bagi pembuat kebijakan (manajer dan pemilik UMKM) dalam upaya menjaga kesehatan mental karyawan.

\section{METODE PENELITIAN}

\section{Jenis Penelitian}

Jenis Penelitian ini adalah penelitian kuantitatif.Pendekatan penelitian untuk penelitian kuantitatif yaitu hasil observasi diukur dengan menggunakan data primer berupa catatan. responden. Analisis ini bertujuan untuk mengevaluasi karakteristik psikologis kuesioner. Memahami tanggapan dan persepsi responden serta perangkat terkait (Sani et al., Tahun 2020).

\section{Waktu dan Tempat Penelitian}

Penelitian ini dimulai pada awal th 2021, dengan tempat penelitian pada Usaha mikro kecil dan menengah (UMKM) di Lampung Timur . 


\section{Target/Subjek Penelitian}

Subjek penelitian ini adalah karyawan UMKM makanan diLampung Timur yang berjumlah 273 responden. Teknik sampling dalam penelitian ini dengan menggunakan Purposive sampling, artinya pengambilan sampel berdasarkan kriteria tertentu.

\section{Prosedur Penelitian}

Prosedur yang peneliti lakukan ada beberapa tahap yaitu :

1. Fase konseptual (membangun masalah dan meninjau literatur spesifik yang relevan dan menentukan kerangka teoritis, menetapkan hipotesis).

2. Tahap desain dan perencanaan (pemilihan desain penelitian, desain rencana pengambilan sampel yang menentukan metode pengukuran variabel penelitian tertentu dalam populasi penelitian, penarikan kesimpulan dan tinjauan desain penelitian, pelaksanaan dan modifikasi pencarian).

3. Membuat kuesioner dan mengumpulkan data penelitian.

4. Tahap demonstrasi (pengumpulan data, persiapan data) analisis) data penelitian dikumpulkan di tempat.

5. tahap analisis (analisis data dan perhitungan hasil data) penelitian) pengolahan dan analisis data penelitian. Data Pemrosesan dan analisis informasi yang dikumpulkan di situs Temuan tersebut meliputi: Kesimpulan dari hasil uji hipotesis penelitian.

6. Tahap Diseminasi, desain hasil studi. di langkah terakhir membaca, memahami dan mengetahui hasil penelitian Untuk kepentingan pembaca, temuan penelitian disajikan sebagai berikut. Kesimpulan dari hasil penelitian.

\section{Data, Instrumen, dan Teknik Pengumpulan Data}

Data utama dalam penelitian ini adalah data primer, yang berupa persepsi responden, yaitu Tenaga Pendidik. Instrumen menggunakan perangkat (tools) berupa kuesioner atau angket. Kuesioner ini diukur dan diukur dengan menggunakan skala Likert. Skala Likert ditetapkan dengan 5 (lima) gradasi dari tingkat sangat tidak setuju sampai dengan setuju (Sugiyono, 2017). Teknik pengumpulan data menggunakan konsep tertutup yaitu angket yang disajikan dalam bentuk seperangkat pernyataan tertulis kepada responden untuk dijawab. Kuesioner adalah suatu teknik pengumpulan informasi yang memungkinkan analis mempelajari sikapsikap, keyakinan, perilaku, dan karakteristik beberapa orang utama di dalam organisasi yang bisa terpengaruh oleh sistem yang diajukan atau oleh sistem yang sudah ada. Dengan 
menggunakan teknik ini akan diperoleh data tentang Potong gaji, PHK, dan Kesehatan Mental.

\section{Teknik Analisis Data}

Teknik analisis data dalam penelitian ini menggunakan rumus regresi linear berganda. dalam Pengujian regresi dibantu dengan pengolahan data pada program SPSS dengan persamaan regresi. Perasamaan analisis regresi linier berganda yang digunakan adalah:

$\mathrm{Y}=\mathrm{a}+\mathrm{b} 1 \mathrm{X} 1+\mathrm{b} 2 \mathrm{X} 2+\mathrm{b} 3 \mathrm{X} 3$ et

Keterangan :

XI : PHK

X2 : Potong Gaji

Y : Kesehatan Mental

a : Intercep / konstanta

b : Koefisien Regresi

et : Error Term (tingkat kesalahan)

\section{HASIL PENELITIAN DAN PEMBAHASAN}

\section{Hasil Penelitian}

Untuk menentukan apakah model memenuhi syarat, dalam penelitian ini dilakukan uji validitas dan realibilitas data. Kriteria uji validitas yaitu, nilai- $p$ signifikan harus kurang dari 0,05 (Hair Et al. , 2013). Hasil uji validitas menunjukkan bahwa nilai signifikan korelasi untuk semua indicator PHK, Potong Gaji, dan Kesehatan Mental Karyawan nilai$p$ signifikan kurang dari 0,05. Oleh karena itu, semua indikator telah memenuhi kriteria validitas. Selanjutnya uji reliabilitas dapat dilihat melalui nilai Cronbach 's alpha. Keduanya harus dinilai di atas 0,70 sebagai syarat keandalan (Hair et al. ,2013 ). Hasil Cronbach 's alpha variable PHK, Potong Gaji, dan Kesehatan Mental Karyawan adalah lebih dari 0,70, sehingga kuesioner dapat dinyatakan reliabel.

Tahap berikutnya yaitu analisis data yang dilakukan dengan uji regresi menggunakan bantuan program SPSS. Berikut ini adalah hasil penelitiannya : 


\section{Tabel 1. Regression analysis}

\begin{tabular}{llll}
\hline Steps & $\boldsymbol{\beta}$ & $\mathbf{t}$ & Sig \\
\hline PHK dan & -0.234 & -3.413 & 0.007 \\
$\begin{array}{l}\text { Kesehatan Mental } \\
\text { Potong Gaji dan }\end{array}$ & -0.568 & -3.847 & 0.002 \\
$\begin{array}{l}\text { Kesehatan Mental } \\
\text { Sumber : Data Primer diolah 2021 }\end{array}$ & &
\end{tabular}

Tabel diatas yang menunjukkan bahwa : Pemutusan Hubungan kerja ( PHK) sebagai variable independent dengan Kesehatan Mental sebagai variable dependent. Hasil analisis data menunjukkan bahwa $(\mathrm{t}=-3.413$, Sig $<0.007)$. Hal ini membuktikan bahwa Pemutusan Hubungan kerja ( PHK) berpengaruh secara negatif terhadap Kesehatan Mental karyawan, dengan Nilai $\beta-0,234$, nilai tersebut memberikan arti bahwa Pemutusan Hubungan kerja ( PHK) mengurangi kesehatan mental atau memperburuk kesehatan mental sebesar -0,234 satuan. Selanjutnya adalah Potong Gaji berpengaruh Negatif terhadap Kesehatan Mental Karyawan, hasilnya adalah didukung dibuktikan dengan nilai $(\mathrm{t}=-3.413$, Sig <0,007), dengan arah koefisien negative.

\section{Pembahasan}

Pandemi Covid-19 berdampak besar pada banyak perusahaan, termasuk UMKM juga mengalami hal yang sama. Semua sector berduka, omset penjualan menurun, sehingga pemilik usaha terpaksa melakukan Pemutusan Hubungan kerja ( PHK). Jikapun tidak melakukan PHK, mereka akan melakukan pemotongan gaji, karena tidak semua karyawan full bekerja. Sistem kerja menjadi shift-shift'an, karyawan secara bergantian bekerjanya, hal ini dikarenakan jumlah pekerjaan yang harus dikerjakan semakin sedikit. Sejatinya di sebagian besar perusahaan, pemotongan gaji bukan alternatif yang berguna bagi orang awam, karena motongan gaji tidak akan bermanfaat untuk mempertahankan banyak karyawan dan karena moral orang yang dirugikan dari pemotongan gaji, Bewley (1998). Potong gaji menimbulkan seseorang merasa tempat bekerja mereka tidak adil. Potong gaji dan PHK berefek negatif dampak psikologis dari waktu ke waktu dapat diterjemahkan menjadi masalah kesehatan fisik (Korpi, 2001).

Pemutusan Hubungan kerja ( PHK) yang dilakukan oleh UMKM di Lampung Timur akan menjadi masalah penting bagi para karyawan. Karyawan memiliki perubahan yang cukup untuk membuat perubahan yang cukup. Hal-hal seperti itu berubah kehilangan perilaku, depresi, harapan, kesenangan, jauh dari kehidupan sosial mereka (Siregar, 2019). 
Hal ini dapat mungkin terjadi pada seseorang yang menjadi korban PHK, karena dirinya menganggap bahwa sudah bekerja dengan baik dan tidak melakukan kesalahan yang merugikan perusahaan. Kejadian PHK tersebut akan menyisakan perasaan trauma untuk untuk bekerja kembali bahkan dapat terjadi pada saat akan memulai mencari pekerjaan yang baru. Ini bisa terjadi pada para korban dari PHK dan juga pada para karyawan yang tersisa. Karyawan yang tersisa mau tidak mau akan merasakan was-was, ketakutan karena tinggal menunggu kapan giliran mereka juga akan di PHK. Perasaan ketakutan tersebut lamakelamaan pada akhirnya akan menimbulkan kesehatan mental karyawan memburuk. Hal ini terbukti dari hasil penelitian ini.

Pemutusan Hubungan kerja ( PHK) berhubungan secara negatif terhadap Kesehatan Mental karyawan, Hipotesis tersebut diterima artinya PHK berpengaruh negatif terhadap karyawan, meskipun karyawan yang tersisa tidak di PHK, akan tetapi terbukti PHK membuat mereka merasa cemas, karena sewaktu-waktu bisa saja mereka yang mendapat giliran di PHK. Kehilangan karir cenderung berdampak negatif pada kesehatan mental karyawan (mis wahrendorf at all, 2013) . Orang-orang dengan kesehatan mental yang lebih buruk berada pada risiko lebih besar untuk diseleksi menjadi pengangguran (Dooley et al. 1996). Kehilangan pekerjaan dapat memberikan tekanan yang lebih berat dan bisa melelahkan secara emosional, jika terjadi pada keadaan lingkungan sekitar sedang dalam keadaan penuh ketidakpastian. Beberapa orang akan mencoba mengontrol semuanya, namun kita juga harus menghadapi kenyataan bahwa tidak semua hal bisa kita kontrol dalam segala situasi. Kehilangan pekerjaan seringkali disamakan seperti saat kehilangan orang-orang terkasih (Fowler, 2019). Kehilangan pekerjaan menjadi salah satu faktor terbesar seseorang mengalami stres hingga mengalami depresi. Bahkan, tidak sedikit juga yang mungkin mengalami gangguan kejiwaan, hal tersebut dapat terjadi apabila stresnya yang dialami tidak dikelola dengan baik, sehingga PHK dapat berdampak pada masalah yang jauh lebih serius terhadap korbannya (Anastasia, 2019). Perasaan marah dan cemas bukanlah suatu hal yang abnormal dalam konteks peristiwa yang penuh dengan suatu tekanan. Namun akan menjadi permasalahan yang serius jika sudah berlarut larut dan mengganggu aktivitas sehari-hari.

Potong Gaji berpengaruh Negatif terhadap Kesehatan Mental Karyawan. Hipotesis tersebut juga diterima, artinya meskipun tidak terkena PHK, tetapi potong gaji memberikan efek negatif terhadap kesehatan mental karyawan.Potong gaji menimbulkan seseorang merasa tempat bekerja mereka tidak adil. Potong gaji dan PHK berefek negatif dampak psikologis dari waktu ke waktu dapat diterjemahkan menjadi masalah kesehatan fisik (Korpi, 2001). Pemotongan gaji secara signifikan terkait dengan depresi dan kecemasan spekulasi Asyla, J. 
(2021). Gaji dipotong kemudian keterbatasan dan kesulitan dalam memenuhi kebutuhan hidup pribadi dan keluarga menjadi pemicu stres. Juga, karena persediaan makanan terbatas, mereka yang memiliki persediaan ragu-ragu untuk membagi persediaan mereka untuk kebutuhan masa depan, hal inilah yang menjadi dasar pemicu kesehatan mental karyawan memburuk seiring berjalannya waktu.

Konflik-konflik yang disebutkan di atas,seperti Pemutusan Hubungan kerja ( PHK) dan pemotongan gaji bisa menjadi tekanan atau beban yang luar biasa. Tekanan ini tidak dikendalikan maka akan berdampak negatif pada kesehatan mental. Hal ini dipengaruhi oleh ketidakstabilan emosi dan emosi individu yang menghadapi paksaan sosial dan ekonomi secara simultan akibat efek pandemi Covid-19. (Rifani \& Rahadi , 2021). Maka dari itu perlu dilakukan perlindungan dan pemenuhan hak-haknya sebagai pekerja. Terutama membahas mengenai adanya perlakuan Pemutusan Hubungan Kerja atau PHK tersebut. Seluruh ketentuan mengenai ketenagakerjaan hingga pemutusan hubungan kerja diatur dalam UndangUndang Nomor 13 Tahun 2003.

\section{KESIMPULAN DAN IMPLIKASI}

Berdasarkan analisis data yang dilakukan pada bab sebelumnya, dapat disimpulkan bahwa : 1). Pemutusan Hubungan kerja ( PHK) berpengaruh negatif terhadap kesehatan mental karyawan. 2). Pemotongan gaji berpengaruh negatif terhadap kesehatan mental karyawan. Hasil penelitian ini diharapkan dapat menjadi masukan bagi pembuat kebijakan (manajer dan pemilik UMKM) dalam upaya menjaga kesehatan mental karyawan. Salah satu cara yang dapat ditempuh untuk menjaga kesehatan mental karyawan adalah dengan memberikan motivasi pada karyawan.

\section{DAFTAR PUSTAKA}

Anastasia Diana, Lilis Setiawati,2019, Sistem Informasi Akuntansi Perancangan Prosedur dan penerapan, Edisi 1, Yogyakarta.: Andi Yogyakarta.

Asyla, J. (2021). Dampak Stress Pada Masyarakat Di Masa Pandemi Covid-19.

Baronowska-Rataj, A., Gebel, M., Gousia, K., Nikolaieva, O., Malgorzata, K., Nizalova, O., ... \& Voßemer, J. (2017). Interdependencies between labour market insecurity and well-being: Evidence from panel data.

Becker, N., \& Wahrendorf, J. (2013). Krebsatlas der Bundesrepublik Deutschland/Atlas of Cancer Mortality in the Federal Republic of Germany 1981-1990. Springer-Verlag. 
Bewley, Truman F. 1998. "Why Not Cut Pay?” European Economic Review 42(3-5): 45990.

Black, J. M., \& Hawks, J. H. (2015). Keperawatan Medikal Bedah: Manajemen klinis untuk Hasil yang Diharapkan. Edisi 8. Jakarta: Salemba Medika.

Caroli, D., Elvira, M., Sagone, \& Elisabetta. (2016). Resilience And psychological WellBeing : Differences For Affective Profiles In Italian Middle And Late Adolescents. International Journal of Developmental And Educational Psychology, 1(1), 149-159. doi:10.17060/ijodaep.2016.n1.v1.237

Citrome, Leslie. 1997. "Layoffs, Reductions-in-Force, Downsizing, Rightsizing: The Case of a State Psychiatric Hospital." Administration and Policy in Mental Health 24(6): 52333.

Dooley, L. M. (1996). Case Study Research and Theory Building. Advances in Developing Human Resources Vol.4 N.3, 4(3), 335-354

Fowler, Mike. S.2019. Animation Background Layout: From Student to Professional.

Gerlach, Knut, David Levine, Gesine Stephan, and Olaf Struck. 2006. “And Pay Cuts : Comparing."

Goldsmith, A. H., Darity, W., \& Veum, J. R. (1996, April). The Impact of labour Force History on Self- Esteem and Its Component Parts, Anxiety, Alieantion and Depression. Journal of Economic Psychology.

Hair et. al,. (2013). A primer on Partial Least Squares Structural Equation Modeling (PLSSEM).

Kemeknaker, 2020

keputusan Menteri Tenaga Kerja No. 150 Tahun 2001 dan keputusan Menteri Keuangan tentang PPh pasal 21 tahun 2003

Korpi, T., \& Levin, H. (2001). Precarious footing: temporary employment as a stepping stone out of unemployment in Sweden. Work, employment and society, 15(1), 127-148.

Kropiewnicki, M. E. (2011). Running the Practice Business Operations The Impact of Layoffs and

Kumar Mishra, S., \& Bhatnagar, D. (2010). Linking emotional dissonance and organizational identification to turnover intention and emotional well-being: A study of medical representatives in India. Human Resource Management: Published in Cooperation with the School of Business Administration, The University of Michigan and in alliance with the Society of Human Resources Management, 49(3), 401-419.

Le, Christine, Clainche Lille, and Lille Économie Management. 2019. "Document de Travail Working Paper The Effects of Mass Layoffs on Mental Health."

Metgud, D. C., Khatri, S., Mokashi, M. G., \& Saha, P. N. (2008). An ergonomic study of women workers in a woolen textile factory for identification of health-related problems. Indian journal of occupational and environmental medicine, 12(1), 14.

Moccia, L., Janiri, D., Pepe, M., Dattoli, L., Molinaro, M., De Martin, V., ... \& Di Nicola, M. (2020). Affective temperament, attachment style, and the psychological impact of the 
COVID-19 outbreak: an early report on the Italian general population. Brain, behavior, and immunity, 87, 75-79.

Morgenthaler, N. G., Struck, J., Alonso, C., \& Bergmann, A. (2006). Assay for the measurement of copeptin, a stable peptide derived from the precursor of vasopressin. Clinical chemistry, 52(1), 112-119.

Oswald \& Wu (2011)n. Nurses Perceptions of Spirituality and Spiritual Care diperoleh tanggal 1 Maret 2017.

Rifani, D. A., \& Rahadi, D. R. (2021). Ketidakstabilan Emosi dan Mood Masyarakat Dimasa Pandemi Covid-19. Jurnal Manajemen Bisnis, 18(1), 22-34.

Siregar, C.J.P., dan Wikarsa, S., 2009, Teknologi Farmasi Sediaan Tablet DasarDasar Praktis, Penerbit Buku Kedokteran EGC, Jakarta. 54 - 55, 98 - 115.

Sugiyono. (2017). Metode Penelitian Kuantitatif Kualitatif dan $R \&$ D. Bandung: Alfabeta.

Sullivan K, Cleary M, Sullivan G. (2006). Bullying in Secondary Schools. California: Corwin Press.

Tsui, Y.-S. L., Tung-Han Yu ( 2013). "The Influence Of Psychological Contract And Organizational Commitment On Hospitality Employee Performance." Social Behavior And Personality 41(3): 443-452

UndangUndang Nomor 13 Tahun 2003 Pasal 156 tentang Ketenagakerjaan

Voßemer, Jonas, Michael Gebel, Olena Nizalova, and Olga Nikolaieva. 2018. "The Effect of an Early-Career Involuntary Job Loss on Later Life Health in Europe." Advances in Life Course Research 35(July 2017): 69-76.

https://doi.org/10.1016/j.alcr.2018.01.001. 